\title{
HUBUNGAN PERILAKU KELUARGA SADAR GIZI DENGAN KEJADIAN STUNTING BALITA DAN EVALUASI PROGRAM
}

\author{
Ria Agustina ${ }^{1}$; Tri Niswati Utami ${ }^{2}$; Asriwati $^{3}$ \\ ${ }^{1}$ Program Studi S2 Ilmu Kesehatan Masyarakat, Institut Kesehatan Helvetia \\ ${ }^{2}$ Fakultas Kesehatan Masyarakat, Universitas Islam Negeri Sumatera Utara Medan \\ ${ }^{3}$ Fakultas Kesehatan Masyarakat, Institut Kesehatan Helvetia \\ Email: ria7146@gmail.com
}

\begin{abstract}
The results of monitoring the nutritional status of children under five years (toddler) at the Puskesmas Sigambal Rantau Selatan Sub-District, Labuhanbatu District short prevalence is still high at $15.31 \%$ and very short $10.15 \%$ in 2017. The study aims to analyze the relationship of nutrition conscious family behavior with incidence of toddler stunting and nutrition awareness family program evaluation. The population was mothers with children aged 12-59 months, 119 people and a sample of 92 people. The sampling technique is a random table technique. Data were analyzed univariate, bivariate and multivariate using multiple logistic regression tests. Qualitative data are data reduction, presentation and conclusion drawing. The results showed that the consumption of various foods $(0,000)$ was related to the incidence of toddler stunting and as a dominant factor. Weighing variables, iodized salt consumption, exclusive breastfeeding and nutritional supplements (vitamin A) are not related. The interview found that the evaluation of the nutrition awareness family program was not yet supported by the availability of health workers, cadre assistants, funds and infrastructure, as well as cross-sectoral implementation. Program indicators were not reached because they did not specialize in the nutrition awareness family program. It is recommended that the Public Health Office establish a special program for Nutrition Awareness Families, increase cross-sector collaboration and add cadre assistants to promote the importance of nutrition for the community.
\end{abstract}

Keywords: family behavior; stunting; program evaluation

\section{PENDAHULUAN}

Stunting merupakan suatu keadaan dimana tinggi badan anak yang pendek pada usia yang sama. Balita dalam proses pertumbahan dan perkembangan tidak selalu ideal sehingga memiliki tinggi badan pendek atau sangat pendek sebagai dampak utama dari kekurangan gizi (Yadika, Berawi, \& Nasution, 2019).

Secara golobal Badan Kesehatan Dunia (WHO) memperkirakan 149 juta anak di bawah usia 5 tahun mengalami stunting tahun 2018. Selanjutnya negara
Afrika (58,8 juta) dan Asia (81,7 juta) menyumbung terbanyak kejadian stunting, menyusul negara Amerika Latin (9,6 juta) dan Karabia 4,8 juta. Balita stunting didominasil negara berpeng-hasilan menengah kebawah sebesar $65 \%$ dari total kejadian stunting (Unicef/ WHO/The World Bank, 2019).

Organisasi Kesehatan Dunia (WHO) menempatkan Indonesia sebagai negara ketiga dengan angka prevalensi stunting tertinggi di Asia pada 2017. Angkanya mencapai 36,4 persen. Namun pada tahun 2018, menurut data Riset 
Kesehatan Dasar (Riskesdas), angkanya terus menurun hingga 23,6 persen. Prevalensi kependekan (sangat pendek dan pendek) tahun 2018 adalah 32,5 persen. Angka prevalensi pendek Kabupaten Labuhan-batu tahun 2018 adalah $16,31 \%$ dan sangat pendek $21.06 \%$ (RISKESDAS, 2018).

Penyebab stunting tidak hanya disebabkan makanan yang kurang tetapi karena penyakit. Anak yang mendapat makanan yang baik tetapi sering menderita penyakit infeksi dapat menderita stunting sehingga penting memberdayakan perilaku keluarga dalam asupan gizi dan kesehatan (Wijayanti \& Nindya, 2017).

Asupan zat gizi merupakan hal penting, bagi tubuh untuk melakukan fungsinya seperti menghasilkan energi, membangun dan memelihara jaringan. Pemberian makanan yang tepat untuk anak dapat menurunkan masalah gizi, dimana anak yang mengkonsumsi makanan beragam memilki tingkat kesehatan yang baik (Frempong, 2019).

Penelitian Torlesse et al. (2016) menjelaskan 40,6\% anak berusia 0-23 bulan diberikan makan sesuai usia. Pemberian makanan berupa ASI eksklusif usia 0-5 bulan. Faktor risiko yang berhubungan signifikan antara lain pendapatan rendah, tidak ada perawatan kesehatan di fasilitas kesehatan, dan partisipasi ibu dalam pemberian makanan.
Salah satu program untuk peningkatan status kesehatan bayi dan balita berbasis keluarga adalah program Kadarzi. Keluarga Sadar Gizi (Kadarzi) adalah suatu keluarga yang mampu mengenal, mencegah dan mengatasi masalah gizi setiap anggotanya (Rachmayanti, 2017).

Hasil survei awal berdasarkan data Pemantauan Status Gizi (PSG) tahun 2017 menunjukkan angka prevalensi pendek di Puskesmas Sigambal Kecamatan Rantau Selatan Kabupaten Labuhanbatu adalah $15,31 \%$, sedangkan prevalensi sangat pendek adalah 10,15 $\%$. Salah satu penyebabnya adalah Program Keluarga Sadar Gizi (Kadarzi) di masyarakat yang dilaksanakan sejak tahun 2011 belum efektif (Puskesmas Sigambal, 2019).

Metode dan intensitas sosialisasi tersebut telah disampaikan tetapi tidak secara rutin disebabkan kurangnya dana, tenaga kesehatan dan kurangnya sarana dan prasarana. Selain itu, masih ada keluarga yang tidak membawa anaknya untuk ditimbang di Posyandu.

Hasil pengamatan di lapangan, ibu balita yang bekerja menjadi penghambat dalam pemberian ASI ekslusif, penganekargaman makanan juga belum dapat dikatakan berhasil karena pendapatan masyarakat yang minim memengaruhi konsumsi makanan masyarakat sehari hari, sehingga penting untuk melakukan evaluasi program Kadarzi, mengingat 
masih terdapat balita yang menderita gizi kurang dan stunting setiap tahunnya. Tujuan penelitian adalah untuk menganalisis hubungan perilaku keluarga sadar gizi dengan kejadian stunting balita dan evaluasi program.

\section{METODE}

Desain penelitian adalah kuantitatif pendekatan cros sectional dan untuk memperkuat temuan dilakukan metode kualitatif. Populasi adalah ibu memiliki balita usia 12-59 bulan 119 orang dan sampel 92 orang dengan teknik tabel random di wilayah kerja Puskesmas Sigambal Kecamatan Rantau Selatan Kabupaten Labuhan-batu pada bulan Desember 2019.

Pengumpulan data melalui penyebaran kuesioner (identitas balita, ibu dan pemberian makanan beraneka ragam), pengamatan penim-bangan berat badan, pemberian ASI eksklusif, dan pemberian suplemen gizi (Vit. A) berdasarkan Kartu Menuju Sehat (KMS)/catatan Posyandu serta konsumsi garam beryodium. Kejadian stunting diukur tinggi badan menurut umur balita.

Jenis kualitas dengan pendekatan fenomenologis. Kegiatan wawancara tentang evaluasi program Kadarzi terdiri dari: input, proses dan output kepada empat orang yaitu kepala puskesmas, tenaga petugas gizi, kader dan ibu balita stunting selama dua minggu.
Sebelum data diberikan kepada responden, terlebih dahulu dilakukan uji validitas dan reliabilitas pada 10 orang ibu balita di Puskesmas Sukamakmur wilayah kerja Puskesmas Sigambar. Hasil uji validitas berdasarkan nilai koefisien $\mathrm{r}_{\text {hitung }}$ pada rentang 0,667-0, $0,897>R_{\text {tabel }}=0,666$, diasumsikan data berdistribusi normal. Hasil nilai Cronbach's $A l p h a_{\text {hitung }}$ berada pada rentang 0,696-0,899>0,666, diasumsikan kuesioner reliabel.

Data kuantitatif dianalisis secara univariat, bivariat dan multivariat melalui uji regresi logistik berganda. Data kualitatif menggunakan metode interaktif untuk menggali informasi aspek pendukung program Kadarzi (input) dan pelaksanaan (proses) dan hasil evaluasi (output) melalui tahapan reduksi data, penyajian dan penarikan kesimpulan.

\section{HASIL DAN PEMBAHASAN}

Hasil analisis univariat dan bivariat disajikan sebagai berikut:

\section{Kuantitatif}

\section{Analisis Univariat}

Analisa univariat menjelaskan tentang karakteristik ibu dan balita serta variabel penelitian ditampilkan pada Tabel 1 dan Tabel 2 di bawah ini: 
Tabel 1. Karakteristik Ibu dan Balita

\begin{tabular}{lcc}
\hline \multicolumn{1}{c}{ Karakteristik Ibu } & n & \% \\
\hline Ibu & & \\
Umur & & 83,7 \\
$\quad 20-35$ tahun & 77 & 16,3 \\
>35 tahun & 15 & 46,7 \\
Pendidikan & & 27,2 \\
$\quad$ SD & 43 & 16,3 \\
SMP & 25 & 4,4 \\
SMA & 15 & 5,4 \\
Diploma & 4 & $\mathbf{\%}$ \\
$\quad$ Sarjana & 5 & 48,9 \\
$\quad$ Karakteristik Balita & $\mathbf{n}$ & 51,1 \\
\hline Jenis Kelamin & & \\
$\quad$ Perempuan & 45 & 23,9 \\
Laki-laki & 47 & 76,1 \\
Umur & & \\
12-23 bulan & 22 & \\
$24-59$ bulan & 70 & \\
\hline
\end{tabular}

Tabel 2. Distribusi Frekuensi Variabel Penelitian

\begin{tabular}{lcc}
\multicolumn{1}{c}{ Variabel } & n & \% \\
\hline Penimbangan Berat Badan & & 72,8 \\
$\quad$ Baik & 67 & 27,2 \\
$\quad$ Belum Baik & 25 & 33,7 \\
Pemberian ASI Eksklusif & 31 & 66,3 \\
$\quad$ Baik & 61 & 57,6 \\
$\quad$ Belum Baik & 53 & 42,4 \\
Makanan Beraneka Ragam & 39 & 98,9 \\
$\quad$ Baik & & 1,1 \\
$\quad$ Belum Baik & 91 & 83,7 \\
Konsumsi Garam Beryodium & 1 & 16,3 \\
$\quad$ Baik & 77 & 58,7 \\
$\quad$ Belum Baik & 15 & 41,3 \\
Pemberian Suplemen Gizi (Vit. A) & & \\
$\quad$ Baik & 54 & \\
$\quad$ Belum Baik & 38 & \\
Kejadian Stunting & & \\
$\quad$ Normal & &
\end{tabular}

Analisis Bivariat

Tabel 3. Hasil Analisis Bivariat

\begin{tabular}{lc}
\hline \multicolumn{1}{c}{ Variabel } & $\boldsymbol{p}$ \\
\hline Penimbangan berat badan & 1,000 \\
Pemberian ASI eksklusif & 0,000 \\
Konsumsi makan beraneka ragam & 0,000 \\
Konsumsi garam beryodium & 0,859 \\
Pemberian suplemen gizi (Vit. A) & 0,862 \\
\hline
\end{tabular}

Setelah dilakukan uji statistik chi kecil dari 0,05, berarti variabel tersebut square, diperoleh nilai $p$ variabel berhubungan dengan kejadian stunting pemberian ASI eksklusif $(0,000)$ dan anak balita. Sedangkan variabel makanan beraneka ragam $(0,000)$ lebih penimbangan berat badan $(1,000)$, 
konsumsi garam beryodium $(0,859)$ dan pemberian suplemen gizi (Vit. A) $(0,862)$ nilai $p$ lebih besar dari 0,05 sehingga variabel tidak berhubungan.

Analisis bivariat berfungsi sebagai persyaratan variabel kandidat model regresi logistik berganda menunjukkan hanya variabel dengan nilai $\mathrm{p}<0,25$, sehingga variabel pemberian ASI eksklusif dan makanan beraneka ragam yang diikutsertakan.

\section{Analisis Multivariat}

Tabel 4. Hasil Analisis Multivariat

\begin{tabular}{lcrrrrr}
\hline \multicolumn{1}{c}{ Variabel } & \multirow{2}{*}{$\boldsymbol{B}$} & \multirow{2}{*}{ Sig. } & \multirow{2}{*}{ OR } & \multicolumn{2}{c}{ 95\% CI for EXP(B) } \\
\cline { 5 - 7 } & & & & Lower & Upper \\
\hline Pemberian ASI eksklusif & 1,450 & 0,103 & 4,265 & 0,744 & 24,436 \\
Konsumsi makan beraneka & 2.578 & 0,000 & 13,175 & 3,721 & 46,646 \\
ragam & 6,245 & 0,000 & 0,002 & & \\
Constanta & & & & & \\
\hline
\end{tabular}

Hasil analisis multivariat, dari kedua variabel ternyata hanya variabel konsumsi makan beraneka ragam memiliki nilai $p<0,005$, artinya ada pengaruh makanan beraneka ragam $\mathrm{OR}=13,175 \quad(95 \% \quad \mathrm{CI} ; \quad 3,721-46,646)$, Sedangkan variabel Pemberian ASI eksklusif nilai $p 0,103>0,05$, berarti tidak berpengaruh.

Konsumsi makan beraneka ragam menjadi faktor paling dominan, dimana berpeluang 13,175 kali menurunkan kejadian stunting anak balita daripada tidak memberikan makanan beragam.

\section{Kualitatif}

Tabel 5. Matrik Evalusi Program Kadarzi

\begin{tabular}{|c|c|c|}
\hline Aspek & & Keterangan \\
\hline \multirow[t]{9}{*}{ Input } & SDM & 1. Belum efektif \\
\hline & & 2. Tugas rangkap \\
\hline & & 3. Selalu datang ke posyandu \\
\hline & Dana & 1. Transport \\
\hline & & 2. Pelatihan/transport \\
\hline & & 3. Pemberian PMT \\
\hline & Sarana Prasarana & 1. Belum mencukupi \\
\hline & & 2. Mendukung \\
\hline & & 3. Ada poster Kadarzi \\
\hline \multirow[t]{4}{*}{ Proses } & & 1. Sosialisasi belum rutin \\
\hline & & 2. Pelaksanaan rutin \\
\hline & & $\begin{array}{l}\text { 3. Penimbangan, vit A dan penyuluhan belum } \\
\text { diikuti jumlah peserta memadai }\end{array}$ \\
\hline & & $\begin{array}{l}\text { 4. Menimbang, imunisasi, pemberian PMT } \\
\text { belum maksimal }\end{array}$ \\
\hline \multirow[t]{4}{*}{ Output } & & 1. Belum mencapai target \\
\hline & & 2. Sebagian mencapai target \\
\hline & & 3. Penyuluhan rutin \\
\hline & & 4. Mengikuti kegiatan posyandu \\
\hline
\end{tabular}




\section{Pembahasan}

Setelah diuraikan hasil penelitian, maka selanjutnya dianalisis sebagai berikut.

Perilaku ibu mengenai penimbangan berat badan pada balita dilakukan secara, namun tidak berkontribusi terhadap kejadian stunting. Hal ini mungkin disebabkan ibu balita membawa anaknya ke Posyandu rutin setiap bulan, namun ada faktor lain lebih dominan memengaruhi stunting pada balita. Hasil penelitian ini berbeda dengan penelitian Vonaesch et al. (2017) dan Yasmin, Kustiyah, dan Dwiriani (2019) di tempat yang berbeda menunjukkan berat badan berhubungan dengan stunting pada balita.

Analisis univariat menjelaskan bahwa ibu yang teratur melakukan pemantauan berat badan anak balita kebanyakan berstatus gizi baik tetapi ditemukan balita mengalami stunting. Hal ini disebabkan karena ibu menimbang berat badan balita secara teratur di Posyandu tetapi tidak diikuti dengan kesadaran dan pengetahuan masyarakat yang baik tentang asuhan energi dan protein dalam kandungan makanan.

Akses Posyandu sebagai alasan ibu tidak mengikuti kegiatan rutin Posyandu setiap bulan. Selain itu, kebiasaan ibu tidak lagi membawa anaknya setelah usia di atas 2 tahun. Berdasarkan kunjungan posyandu bulan Desember tahun 2019 usia anak di bawah $\leq 2$ tahun sebanyak 98 orang dan $>2$ tahun 39 orang.

Hasil wawancara dengan ibu memiliki balita stunting, mengatakan pola pengasuhan kurang diperhatikan, maka balita lebih sering sakit karena beberapa penyakit infeksi. Kejadian penyakit infeksi yang berulang tidak hanya berakibat pada menurunnya berat badan atau tampak pada rendahnya nilai indikator berat badan menurut umur, akan tetapi juga indikator tinggi badan menurut umur.

Informan sebagai petugas kesehatan dan kader mengatakan faktor masih ditemukan kasus stunting cukup tinggi disebabkan jumlah tenaga kesehatan, tidak ada dana transprotasi, serta fasilitas belum mendukung terutama menjaring anak datang ke posyandu untuk ditimbang dan ibu diberikan pendidikan kesehatan (sosialisasi).

Perilaku ibu tentang pemberian ASI eksklusif tidak berhubungan dengan kejadian stunting pada anak balita. Penelitian serupa oleh Rusmil, Prahastuti, Erlangga Luftimas, dan Hafsah (2019), tidak ada hubungan pemberian ASI eksklusif dengan stunting di Puskesmas Jatinangor. Berbeda dengan penelitian Torlesse et al. (2016) di tiga kabupaten Indonesia (Klaten Sikka, Jayawijaya) dan Mzumara (2018) di Zambia. Rachmi et al. (2016) mengemukakan bahwa anak-anak yang disapih sebelum 6 bulan 
memiliki kemungkinan stunting yang jauh lebih tinggi.

$$
\text { Hasil temuan penelitian }
$$
menunjukkan bahwa pemberian ASI eksklusif sudah baik. Namun masih ada ibu tidak memberi ASI eksklusif kepada balita tetapi tidak mengalami stunting. Hal ini disebabkan ASI diganti dengan susu formula yang aksesnya mudah diperoleh di warung/kedai. Keadaan ini berkaitan perilaku ibu mementingkan kebutuhan susu anak balita didukung pendapatan cukup tinggi. Ibu juga mendapatkan dukungan dari keluarga terutama suami atau teman mendorong agar anak tidak rewel diberi minum susu formula dan makanan encer lainnya sebelum usia 6 bulan agar lebih cepat pertumbuhannya.

Hasil wawancara dengan ibu diketahui bahwa balita yang memiliki status gizi baik walaupun tidak diberi ASI eksklusif diganti dengan susu formula sehingga mendapat asupan gizi yang cukup. Selain itu, balita mendapatkan suplemen penambah nafsu makan atau dari makanan yang dikonsumsi seharihari. Walaupun kelemahan susu formula tidak mengandung zat antibodi seperti ASI namun tetap sebagai sumber vitaman dan mineral dalam menghambat stunting. Selain itu, balita diberik susu susu formula lebih rawan terkena penyakit. Hasil temuan di lapangan riwayat infeksi berulang balita pernah trejadi seperti diare, infeksi saluran pernafasan atas, dan infeksi lainnya memengaruhi partum-buhan tinggi dan berat badan.

Hasil evaluasi program Kadarzi kepada masyarakat belum berjalan efektif. Pemberian ASI ekslusif dan kegiatan penyuluhan hanya sebagian kecil diikuti oleh ibu memiliki balita menyebabkan indikator pemberian ASI mencapai 78,5\% (target 85\%).

Pola asuh ibu terhadap anaknya juga merupakan salah satu faktor yang dapat memengaruhi status gizi balita. Alasan ibu tidak memberikan ASI yang paling banyak adalah ASI tidak lancar. Selain itu, ibu bekerja dan bayi masih rewel meskipun sudah diberi ASI. Mudahnya mendapatkan susu formula membuat ibu kurang berusaha untuk meningkatkan produksi ASI (Cynthia, Suryawan, \& Widiasa, 2019).

Perilaku ibu terkait pemberian makanan beraneka ragam berhubungan dengan kejadian stunting pada anak balita. Sejalan dengan penelitian Simanjuntak, Haya, Suryani, Khomsan, dan Ahmad (2019) bahwa praktik gizi ibu dengan makanan tradisional memiliki hubungan yang signifikan dengan stunting di Kabupaten Bengkulu Tengah.

Pada umumnya menu keluarga sudah beragam jenisnya terdiri dari nasi, sayur, ikan dan makanan lainnya. Namun ada baltia yang diberi makanan keanekaragam tetapi mengalami stunting. 
Kondisi ini disebabkan ada riwayat anak balita menderita penyakit infeksi.

Sesuai dengan hasil wawancara dengan ibu diketahui bahwa sebagian besar telah mengkonsumsi makanan beraneka ragam untuk memenuhi kebutuhan zat gizi. Ada beberapa balita yang telah mengkonsumsi makanan yang beraneka ragam tetapi karena adanya penyerapan makanan yang terganggu akibat penyakit infeksi yang diderita anak menyebabkan tidak terpenuhi kebutuhan gizinya.

Hasil pengamatan diperoleh informasi bahwa anak yang mengalami gangguan kesehatan seperti demam atau diare karena anak sering tidak menggunakan sandal saat bermain sehingga masuk angin. Pada awal gejala tidak langsung di bawa ke Puskesmas tetapi diobati dengan resep tradisional seperti digosok dengan minyak kayu putih atau minyak makan dicampau bawang berah serta membeli obat di kedai. Menurut Mzumara, Bwembya, Halwiindi, Mugode, dan Banda (2018) bahwa stunting pada balita merupakan penghambatan pertumbuhan disebabkan faktor asupan makanan yang tidak memadai dan kondisi kesehatan yang buruk.

Konsumsi makan beraneka ragam kepada anak balita menjadi faktor paling dominan, dimana berpeluang 13,175 kali menurunkan kejadian stunting anak balita daripada tidak memberikan makanan beragam. Sesuai dengan penelitian di Ghana menunjukkan bahwa anak yang makan beraneka ragam dengan jumlah yang sesuai meningkatkan kesehatan dan menurunkan masalah gizi dibandingkan anak yang tidak mengkonsumsi makanan beraneka ragam (Fekadu, Mesfin, \& Haile, 2019).

Perilaku ibu mengenai penggunaan garam beryodium pada umumnya sudah baik, tetapi tidak berhubungan dengan kejadian stunting pada anak balita. Bebeda dengan penelitian Krämer et al. (2016) mengatakan bahwa tidak tersedianya garam beryodium berpeluang 3\% mengalami stunting. Kekurang garam beryodium juga berpeluang kekurangan berat badan sebesar $5 \%$.

Analisis univariat menjelaskan hampir seluruh ibu $(98,9 \%)$ telah menggunakan garam mengandung yodium lebih dari $30 \mathrm{ppm}$ sehingga tidak terlihat dampaknya dalam penilaian status gizi balita. Walaupun ibu telah menggunakan garam beryodium namun masih terdapat balita dengan status gizi stunting. Sesuai hasil observasi terhadap garam yang ada di rumah ibu diketahui bahwa cara penyimpanan garam yang terbuka serta letak garam berada di dekat kompor dapat mengganggu komposisi garam tersebut.

Ditinjau dari segi gizi kandungan garam beryodium tersebut, tentunya 
belum dapat memenuhi kebutuhan gizi yag dibutuhkan tubuh balita. Pada umumnya konsumsi garam beryodium mengandung zat yodium agar anak terhindari dari gejala tiroid. Walaupun kebiasaan keluarga memasak makanan menggunakan garam beryodium tetapi besar kemungkinan stunting, apabila tidak didukung keanekaragaman makan lain.

Perilaku ibu mengenai pemberian vitamin A pada umumnya sudah baik, tetapi berhubungan dengan kejadian stunting pada anak balita. Penelitian Sanin et al. (2018), mengatakan rasio kecukupan gizi rata-rata (mean adequacy ratio) tidak berhubungan dengan stunting usia 12-24 bulan di daerah kumuh Bangladesh.

Konsumsi suplemen nutrisi berbasis lipid dalam jumlah kecil (SQ-LNS) terdiri dari mikronutrien dan makronutrien diberikan selama lebih dari 6 bulan mengurangi kejadian stunting (RR 0,35) pada bayi 6-12 bulan dibandingkan bayi dengan kelompok kontrol (Muslihah, Khomsan, Briawan, \& Riyadi, 2016).

Alasan keluarga belum membawa anak balita ke Posyandu untuk mendapatkan kapsul vitamin A secara serentak dikarenakan keluarga tidak mengetahui jadwal pemberian kapsul vitamin A. Hal tersebut terjadi karena balita jarang dibawa ke posyandu sehingga akhirnya keluarga tidak memperoleh informasi jadwal pemberian kapsul tersebut. Keluarga belum mengetahui tentang pentingnya manfaat vitamin A pada anak. Menurut Edmond bahwa vitamin A adalah mikronutrien penting dalam butuh. Kekurangan vitamin A mempengaruhi sintesis protein, sehingga mempengaruhi pertumbuhan sel pada anak (Wu, 2016).

Hasil wawancara terhadap ibu diketahui bahwa meskipun sebagian besar balita telah diberikan suplemen vitamin A dosis tinggi kepada balita sehingga memiliki status gizi yang baik. Namun balita yang tidak mengkonsumsi suplemen vitamin A dosis tinggi juga memiliki status gizi yang baik. Kebutuhan vitamin A kemungkinan sudah terpenuhi dari zat makanan lain. Ibu jarang membiasakan memberikan konsumsi sayuran yang banyak mengandung vitamin A seperti kacangkacangan kepada balita, sedangkan buah, susu dan hati sapi masih terlalu sulit dijangkau oleh pendapatan keluarga.

Pemberian vitamin A dapat diperoleh dengan memberikan berbagai aneka lauk pauk seperti sayuran dan buah-buahan. Menurut National Institutes of Health. (2020) bahwa sumber vitamin A dapat diperoleh dari sayuran, buah-buahan, biji-bijian, susu bebas lemak atau rendah lemak dan produk susu, ikan, hati sapi dan minyak. 
Persentase Kadarzi di wilayah Puskesmas Sigambal $(59,47 \%)$. Tingkat kesadaran gizi di tingkat Puskesmas masih dibawah target nasional yaitu 80\%. Dimasa mendatang perlu ditingkatkan sosialisasi dan penyuluhan secara merata agar keluarga manfaat dari program tersebut khususnya mencegah stunting pada anak balita.

\section{KESIMPULAN DAN SARAN}

Secara statistik faktor yang dapat mengurangi kejadian stunting pada anak balita adalah pemberian makanan beraneka ragam. Sedangkan penimbangan berat badan, pemberian ASI eksklusif, konsumsi garam beryodium dan pemberian suplemen gizi (Vit. A) lemah pengaruhnya.

Disarankan meningkatkan status gizi keluarga dengan meningkatkan pengetahuan keluarga tentang pemberian makanan beraneka ragam dengan rutin mengikuti kegiatan Posyandu dan dapat meng-elola makanan dari bahan makanan yang murah dan mudah diperoleh. Pembekalan kader tentang teknik promosi kesehatan yang efektif untuk membantu petugas kesehatan dalam upaya penerapan program sadar gizi.

\section{DAFTAR PUSTAKA}

Cynthia, Suryawan, I. W. B., \& Widiasa, A. (2019). Hubungan riwayat ASI Eksklusif dengan kejadian stunting pada anak Usia 1259 Bulan di RSUD Wangaya Kota
Denpasar. Jurnal Kedokteran Meditek.

Fekadu Y, Mesfin A, Haile D, S. B. (2019). Factors associated with nutritional status of infants young children in Somal Region, Ethiopia.

Frempong RBF, A. S. (2019). Dietery diversity and child malnutrition in Ghana.

Kemenkes RI. (2018). Hasil Utama Riset Kesehatan Dasar Tahun 2018. Kementrian Kesehatan Republik Indonesia. https://doi.org/1 Desember 2013

Krämer, M., Kupka, R., Subramanian, S. V., \& Vollmer, S. (2016). Association between household unavailability of iodized salt and child growth: Evidence from 89 demographic and health surveys. American Journal of Clinical Nutrition, 104(4), 1093-1100. https://doi.org/10.3945/ajen.115.1247 19

Muslihah, N., Khomsan, A., Briawan, D., \& Riyadi, H. (2016). Complementary food supplementation with a smallquantity of lipid-based nutrient supplements prevents stunting in 612-month-old infants in rural West Madura Island, Indonesia. Asia Pacific Journal of Clinical Nutrition. https://doi.org/10.6133/apjen.122016. s9

Mzumara, B., Bwembya, P., Halwiindi, H., Mugode, R., \& Banda, J. (2018). Factors associated with stunting among children below five years of age in Zambia: evidence from the 2014 Zambia demographic and health survey. BMC Nutrition, 4(1), 1-8. https://doi.org/10.1186/s40795018-0260-9

National Institutes of Health. (2020). Levels and trends in child malnutrition. Retrieved from https://ods.od.nih.gov/factsheets/Vita minA-HealthProfessional/\#h4.

Puskesmas Sigambal. (2019). Profil Puskesmas Sigambal Kecamatan Rantau Selatan Kabupaten Labuhanbatu. 
Rachmayanti, R. D. (2017). Pengenalan program Kadarzi di Kelurahan Wonokusumo Surabaya. Media Gizi Indonesia, 13(2), 176-182. https://doi.org/10.20473/mgi.v13i2.1 76

Rachmi, C. N., Agho, K. E., Li, M., \& Baur, L. A. (2016). Stunting coexisting with overweight in $2 \cdot 0$ 4.9-year-old Indonesian children: Prevalence, trends and associated risk factors from repeated crosssectional surveys. Public Health Nutrition, 19(15), 2698-2707. https://doi.org/10.1017/S1368980016 000926

Rusmil, V. K., Prahastuti, T. O., Erlangga Luftimas, D., \& Hafsah, T. (2019). Exclusive and non-exclusive breastfeeding among stunted and normal 6-9 month-old-children in Jatinangor Subdistrict, Indonesia. Althea Medical Journal, 6(1), 35-41. https://doi.org/10.15850/amj.v6n1.15 98

Sanin, K. I., Munirul Islam, M., Mahfuz, M., Shamsir Ahmed, A. M., Mondal, D., Haque, R., \& Ahmed, T. (2018). Micronutrient adequacy is poor, but not associated with stunting between 12-24 months of age: A cohort study findings from a slum area of Bangladesh. PLoS ONE, 13(3), 1-17. https://doi.org/10.1371/journal.pone. 0195072

Simanjuntak, B. Y., Haya, M., Suryani, D., Khomsan, A., \& Ahmad, C. A. (2019). Maternal knowledge, attitude, and practices about traditional food feeding with stunting and wasting of toddlers in farmer families. Kesmas: National Public Health Journal, 14(2), 58-64. https://doi.org/10.21109/kesmas.v14i 2.2712

Torlesse, H., Cronin, A. A., Sebayang, S. K., \& Nandy, R. (2016). Determinants of stunting in Indonesian children: Evidence from a cross-sectional survey indicate a prominent role for the water, sanitation and hygiene sector in stunting reduction. BMC Public
Health, 16(1), 1-11. https://doi.org/10.1186/s12889-0163339-8

Unicef/ WHO/The World Bank. (2019). Levels and Trends in Child malnutrition - Unicef WHO The World Bank Joint Child Malnutrition Estimates, key findings pf the 2019 edition. Unicef, 4. https://doi.org/10.1016/S02666138(96)90067-4

Vonaesch, P., Tondeur, L., Breurec, S., Bata, P., Nguyen, L. B. L., Frank, T., ... Vray, M. (2017). Factors associated with stunting in healthy children aged 5 years and less living in Bangui (RCA). PLoS ONE, 12(8). https://doi.org/10.1371/journal.pone. 0182363

Wijayanti, S., \& Nindya, T. S. (2017). Relationship of kadarzi (family conscious nutrition) behavior practice to nutritional status of children under five years in Tulungagung District. Amerta Nutrition, 1(4), 379-388. https://doi.org/10.20473/amnt.v1.i4.2 017.378-388

$\mathrm{Wu}, \mathrm{G}$. (2016). Dietary protein intake and human health. Food and Function, 7(3), 1251-1265. https://doi.org/10.1039/c5fo01530h

Yadika, A. D. N., Berawi, K. N., \& Nasution, S. H. (2019). Pengaruh stunting terhadap perkembangan kognitif dan prestasi belajar. Jurnal Majority, 8(2), 273-282.

Yasmin, G., Kustiyah, L., \& Dwiriani, C. M. (2019). Stunted children has higher risk of overweight: a study on children aged 6-12 years in eight provinces in Indonesia. Pakistan Journal of Nutrition, 18(5), 455-463. https://doi.org/10.3923/pjn.2019.455. 463 